Ministry of Science and Higher Education of the Russian Federation Ural Federal University named after the first President of Russia B.N. Yeltsin Ural Humanitarian Institute Department of Political Science and Sociology Institute of Modern Management Technologies

\title{
XXIII International Conference "Culture, Personality, Society in the Conditions of Digitalization: Methodology and Experience of Empirical Research" named after professor L.N. Kogan
}

\section{9- 21 March, 2020 \\ Yekaterinburg}

conference proceedings XXIII International Conference "Culture, Personality, Society in the Conditions of Digitalization: Methodology and Experience of Empirical Research" named after professor L.N. Kogan, 19-21 March, 2020, Yekaterinburg, Russia. . - Yekaterinburg, UrFU, 2020

Published: 21 January 2021

Publishing services provided by Knowledge E

Selection and Peer-review under the responsibility of the XXIII International Conference Conference Committee.
S OPEN ACCESS

\section{Editorial board:}

Grunt Elena., doctor, professor, Ural Federal University, Yekaterinburg, Russia Guzikova Maria, assistant-professor, Ural Federal University, Yekaterinburg, Russia Merenkov Anatoly, doctor, professor, Ural Federal University, Yekaterinburg, Russia Suhkova Oksana,assistant-professor, Institute of Modern Management Technologies, Yekaterinburg, Russia

Zyryanov Sergey, doctor, professor, Chelyabinsk branch of Russian Presidential Academy of National Economy and Public Administration, Chelyabinsk, Russia

Sharonova Svetlana, doctor, professor, Peoples' Friendship University, Moscow, Russia Vasilenko Ludmila, doctor, professor, Russian Presidential Academy of National Economy and Public Administration, Moscow, Russia

Vasilkova Valeria, doctor, professor, Saint- Petersburg State University, Saint- Petersburg, Russia

Ibragimov Radiy, doctor, professor, Khakass State University named after Katanova, Abakan, Republic of Khakassia, Russia

Benin Vladislav, doctor, professor, Bashkortastan State University, Ufa, Russia

Sannikova Olga, doctor, professor, Udmurt State University, Izhevsk, Russia 
Shapovalova Inna, doctor, professor, Belgorod State University, Belgorod, Russia

Kozlovsky Vladimir, doctor, professor, The Sociological institute of the Russian Academy of Sciences, Saint Petersburg State University,St. Petersburg, Russia,

Campa Riccardo, PHD, professor, Jagiellonian University in Krakow, Poland

Lissitsa Sabina, PHD, professor, Ariel University, Ariel, Israel

Simons Gregory, Phd, professor, Uppsala University, Uppsala, Sweden

Semenova Yulia, PHD, Kharkiv State Academy of Physical Culture, Kharkiv, Ukraine

The conference proceedings are intended for sociologists, political scientists, philosophers and everyone who is interested in these problems.

Department of Political Science and Sociology,

Ural Humanitarian Institute,

Ural Federal University named after the first President of Russia B.N. Yeltsin ISBN 978-5-91256-474-1 